\title{
The protein and calorie efficiency of rabbits
}

\author{
By R. B. BRADFIELD* AND L. A. MAYNARD \\ School of Nutrition, Cornell University, Ithaca, N.Y., U.S.A. \\ (Received 23 February 1957-Revised 6 August 1957)
}

The shortages of meat during the last world war stimulated the use of the rabbit as a meat animal. A series of studies was carried out by Hutchinson $(1947 a, b)$ and Hutchinson \& Baker (1949) dealing with the nutrition of domestic rabbits. The possibilities of the rabbit as a meat animal for underdeveloped areas stimulate further study. This paper reports a study of the efficiency of conversion of feed protein and energy into edible body protein and calories.

\section{EXPERIMENTAL}

Two experiments were conducted, the first during the spring months, the second during the summer months. In each study, eight weanling New Zealand White does, aged 6 weeks, were obtained from a commercial grower. Two animals, about the average weight of the group, were killed at the beginning of the study. The remaining six were killed at the end of the 8-week experimental period. The same experimental procedures were used for both groups.

The rabbits were ear-marked for identification purposes and individually housed in metal cages with wire floors. They were fed and watered daily and food consumption and weight gain determined weekly.

The ration used was a pelleted commercial ration, GLF Bunny Pellets (Canandaigua, New York). It has the following percentage composition: wheat bran, 7.5 ; standard cuts (whole wheat), 20.5; wheat germ (flour millings), $5 \cdot 0$; soya-bean meal, 15.0 ; ground oats, $20 \cdot 0$; maize meal, I2.725; dehydrated alfalfa meal, I $6 \cdot 5$; limestone, $1 \cdot 0$; dicalcium phosphate, $0 \cdot 75$; sodium chloride, $\mathrm{r} \cdot 0$; irradiated yeast, type $9 \mathrm{~F}$ (9000 i.u./g vitamin D, Standard Brands Inc. New York), 0.025 . On a moisture-free basis the diet contained $20.24 \%$ protein, $6.03 \%$ ash and $4.63 \mathrm{Cal} . / \mathrm{g}$. To minimize wastage, the feeding utensils were equipped with a lip, and the receptacles were filled to only onehalf of their capacity. The small amount of food wasted was weighed and subtracted from the total amount of food. Random samples of the ration were taken weekly and a composite sample was analysed for dry matter, ash, protein ( $\mathrm{Nx} 6 \cdot 25)$, and energy (bomb calorimeter).

For carcass analysis, the animals were killed with an overdose of Nembutal (Abbott Laboratories, North Chicago, Ill.) and the head and paws removed with the aid of a meat cleaver. The animals were then bled and skinned as rapidly as possible. The gastro-intestinal and urogenital tracts and the respiratory system were removed and the remainder was taken as carcass weight.

* Present address, Institute of Inter-American Affairs, U.S. Embassy, Lima, Peru. 
The edible portion was defined as muscle meat, liver, kidneys, heart, and the fatty deposits surrounding the kidneys, over the shoulder, and on the pelvic region. The meat was removed from the bones as completely as possible with a knife. The small amount of meat that could not be cut away from the bones was removed by autoclaving them for several minutes, and was added to the edible portion. The edible portion was weighed and minced, and then dried in a freeze-drier (Desivac $138-\mathrm{D}$, F. J. Stokes Machine Co., Philadelphia, Pa., U.S.A.). The dry material was then passed three times through a fine-screened meat grinder, mixed on paper according to standard quantitative procedures, and bottled for analysis. The samples were kept in cold storage until the time of analysis, when dry matter, ash, protein, and energy were determined.

\section{RESULTS}

Food efficiency was defined as the ratio, food consumed $(\mathrm{g})$ : weight gained $(\mathrm{g})$. At the end of the 8-week period the groups averaged 4.04 and 3.47 , respectively, on this basis. The individual results for both experiments are shown in Table $\mathbf{I}$.

Table I. Efficiency of food utilization by rabbits over an 8-week period (ratio, air-dry food $(g)$ :live-weight gain $(g))$. The rabbits were 6 weeks old at the beginning of the experiment

$\begin{array}{ccc}\text { Animal no. } & \text { Exp. I } & \text { Exp. 2 } \\ \text { I } & 3.96 & 3.52 \\ 2 & 3.98 & 3.75 \\ 3 & 4.12 & 3.44 \\ 4 & 3.91 & 3.52 \\ 5 & 4.06 & 2.95 \\ 6 & 4.20 & 3.65 \\ \text { Mean } & 4.04 & 3.47\end{array}$

The carcass weights and content of edible portion of the two groups are shown in Table 2. Carcass weight and edible portion are defined on pp. 13, I4. In general, it may be said that the carcass weight was about $60 \%$ of the live weight, and that the edible portion varied from $5 \mathrm{I}$ to $59 \%$ of the live weight.

The analytical results for the edible portion are shown in Table 3 . On a moisturefree basis the edible portion of the two groups averaged, respectively, $50 \cdot 55$ and $50^{\circ}$ I I $\%$

Table 2. Live weight, carcass weight, and edible portion of rabbits killed at $\mathrm{I} 4$ weeks of age

\begin{tabular}{|c|c|c|c|c|c|c|}
\hline \multirow[b]{2}{*}{$\begin{array}{c}\text { Animal } \\
\text { no. }\end{array}$} & \multicolumn{3}{|c|}{ Exp. I } & \multicolumn{3}{|c|}{ Exp. 2} \\
\hline & $\begin{array}{l}\text { Live wt } \\
\text { (g) }\end{array}$ & $\begin{array}{l}\text { Carcass wt } \\
\text { (as percentage } \\
\text { of live wt) }\end{array}$ & $\begin{array}{l}\text { Edible portion } \\
\text { (as percentage } \\
\text { of live wt) }\end{array}$ & $\begin{array}{l}\text { Live wt } \\
\text { (g) }\end{array}$ & $\begin{array}{c}\text { Carcass wt } \\
\text { (as percentage } \\
\text { of live wt) }\end{array}$ & $\begin{array}{c}\text { Edible portion } \\
\text { (as percentage } \\
\text { of live wt) }\end{array}$ \\
\hline I & 3 I89 & $5^{8 \cdot 8}$ & $55^{\cdot 2}$ & 3565 & $58 \cdot 8$ & $52 \cdot 8$ \\
\hline 2 & 2676 & $60 \cdot 2$ & $56 \cdot 0$ & 3420 & $58 \cdot 8$ & $51 \cdot 7$ \\
\hline 3 & 3077 & $62 \cdot 3$ & $58 \cdot 9$ & 3276 & $57 \cdot 8$ & $50 \cdot 7$ \\
\hline 4 & 3528 & $56 \cdot 6$ & $53 \cdot 0$ & 2995 & 59.4 & $52 \cdot 0$ \\
\hline 5 & 3460 & $60 \cdot 3$ & $57 \cdot 0$ & 3552 & $60 \cdot 2$ & $52 \cdot 9$ \\
\hline 6 & 3318 & $6 r \cdot 3$ & $57 \cdot 3$ & 2657 & 60.9 & $53^{\circ} \circ$ \\
\hline Mean & 3208 & $59 \cdot 9$ & $56 \cdot 2$ & 3244 & $59 \cdot 3$ & $52 \cdot 2$ \\
\hline
\end{tabular}


protein, 3.07 and $3.17 \%$ ash, and 6.97 and $6.85 \% \mathrm{Cal} . / \mathrm{g}$. The animals killed at the beginning of the experiment were, on a percentage basis, higher in protein and in ash content, but lower in energy value.

From the analytical and growth results the protein and calorie efficiencies were calculated. Efficiency was defined as the ratio of output of edible meat to food input or, more simply, the percentage of protein or calories fed recovered in the edible portion. For calories, for example, the calculation was made as follows. The input

Table 3. Protein, ash and energy values of the edible portion of rabbits (moisture-free basis)

\begin{tabular}{|c|c|c|c|c|c|c|}
\hline \multirow[b]{2}{*}{$\begin{array}{c}\text { Animal } \\
\text { no. }\end{array}$} & \multicolumn{3}{|c|}{ Exp. I } & \multicolumn{3}{|c|}{ Exp. 2} \\
\hline & $\begin{array}{c}\text { Protein } \\
(\%)\end{array}$ & $\begin{array}{l}\text { Ash } \\
(\%)\end{array}$ & $\begin{array}{l}\text { Energy } \\
\text { (Cal./g) }\end{array}$ & $\begin{array}{c}\text { Protein } \\
(\%)\end{array}$ & $\begin{array}{l}\text { Ash } \\
(\%)\end{array}$ & $\begin{array}{l}\text { Energy } \\
\text { (Cal./g) }\end{array}$ \\
\hline I & $50 \cdot 28$ & 3.21 & $7 \cdot 12$ & $55 \cdot 08$ & $3 \cdot 19$ & 6.64 \\
\hline 2 & 57.07 & $3 \cdot 42$ & $6 \cdot 90$ & 47.04 & $2 \cdot 96$ & $7 \cdot 08$ \\
\hline 3 & $49^{\circ} 99$ & $2 \cdot 72$ & $6 \cdot 6_{5}$ & $4^{8 \cdot 7^{8}}$ & $3 \cdot 08$ & $6 \cdot 99$ \\
\hline 4 & 54.55 & 3.40 & $6 \cdot 79$ & 47.09 & 3.01 & $6 \cdot 89$ \\
\hline 5 & $47 \cdot 34$ & 2.90 & $7 \cdot 14$ & $49 \cdot 32$ & $3 \cdot 17$ & 6.93 \\
\hline 6 & 44.04 & $2 \cdot 75$ & $7 \cdot 20$ & $53 \cdot 33$ & $3 \cdot 63$ & $6 \cdot 59$ \\
\hline Mean & $50 \cdot 55$ & 3.07 & $6 \cdot 97$ & $50 \cdot 11$ & $3 \cdot 17$ & $6 \cdot 85$ \\
\hline $\begin{array}{l}A^{*} \\
B^{*}\end{array}$ & $\begin{array}{l}71 \cdot 52 \\
66 \cdot 82\end{array}$ & $\begin{array}{l}5 \cdot 48 \\
4 \cdot 87\end{array}$ & $\begin{array}{l}5.72 \\
5.87\end{array}$ & $\begin{array}{l}80 \cdot 19 \\
78 \cdot 10\end{array}$ & $\begin{array}{l}5 \cdot 43 \\
5 \cdot 41\end{array}$ & $\begin{array}{l}5 \cdot 80 \\
5 \cdot 85\end{array}$ \\
\hline Mean & $69 \cdot 17$ & $5 \cdot 18$ & 5.80 & $79 \cdot 15$ & $5 \cdot 42$ & $5 \cdot 83$ \\
\hline
\end{tabular}

Table 4. Percentage recovery in the edible portion of the carcasses of protein and calories consumed by the rabbits in the food

\begin{tabular}{|c|c|c|c|c|}
\hline \multirow{2}{*}{$\begin{array}{c}\text { Animal } \\
\text { no. }\end{array}$} & \multicolumn{2}{|c|}{ Protein } & \multicolumn{2}{|c|}{ Calories } \\
\hline & Exp. I & Exp. 2 & Exp. I & Exp. 2 \\
\hline I & I $7 \cdot 45$ & I $8 \cdot 46$ & $12 \cdot 39$ & $I I \cdot 26$ \\
\hline 2 & $19.6 \mathrm{r}$ & 13.75 & $1 I \cdot 6 I$ & II 54 \\
\hline 3 & $18 \cdot 02$ & $13 \cdot 18$ & I I 8 I & 10.65 \\
\hline 4 & 18.08 & $12 \cdot 51$ & 10.88 & 10.62 \\
\hline 5 & I $8 \cdot 28$ & $15 \cdot 14$ & $13 \cdot 75$ & II 46 \\
\hline 6 & $16 \cdot 16$ & 10.59 & $13.5^{8}$ & $7 \cdot 58$ \\
\hline Mean & $17 \cdot 93$ & 13.94 & $12 \cdot 34$ & 10.52 \\
\hline
\end{tabular}

was the total weight (g) of dry food consumed multiplied by the number of Cal./g dry food. The output was obtained as the product of the total weight $(\mathrm{g})$ of dry edible portion multiplied by the number of Cal./g of dry edible portion. Since the animals were placed on the experimental diets at 6 weeks of age, a correction had to be made for the amount of edible portion that the animals possessed at the outset of the experiment. For this purpose two rabbits, representative of the group at the outset of the experiment, were killed at the beginning of the study, and the edible portion was analysed giving the results shown under A and B in Table 3. The mean results were used to compute what might be considered the average protein and calorie content of the individuals at the beginning. These values were then subtracted from 
the corresponding values for each individual at the close of the experimental period, giving for each an estimate of the protein and calories stored during the period. These values were used to obtain the percentage of protein and calories that were stored. The resulting values are shown in Table 4. It will be noted that for the two experimental groups the mean protein recoveries were 17.93 and $13.94 \%$, and the mean calorie recoveries, 12.34 and $10.52 \%$.

\section{DISCUSSION}

A strict comparison of the groups fed on the stock diet during Exps. I and 2 is limited by several factors. Faecal microscopic checks at the outset of the study revealed 100\% incidence of coccidiosis in Exp. 2. There was no evidence of coccidiosis in the animals of Exp. I. This condition may have caused, in part, the difference in weight of $16 \mathrm{I} g$ between the two groups at the beginning of the experiment ( 1377 and $1216 \mathrm{~g}$, respectively). It is interesting to note that the weights of the animals in Exp. 2 increased sufficiently during the ist week, so that the average weights for the two groups were similar at the end of the Ist week ( 1553 and $1590 \mathrm{~g}$, respectively). Also, the weights of the animals in Exps. I and 2 were nearly identical at the end of the study ( 3208 and $3244 \mathrm{~g}$, respectively). In addition, the first experiment was performed during the early spring months in a room not adequately heated, whereas the second experiment was conducted during the summer months.

The mean food efficiency for each of the two experimental groups was 4.04 and $3.47 \mathrm{~g}$ food/g gain, respectively, at the end of the 8-week experimental period. These results may be compared with those of Huang, Ulrich \& McCay (1954), who weaned rabbits at 5 weeks and obtained for the first 6 weeks after weaning a mean food efficiency of $2 \cdot 7$. The mean food efficiency for the 12-week period after weaning was 3.7. The values for an 8-week period in our study would be expected to fall between the 6- and 12 -week means and this was so.

The chicken is regarded as one of the most efficient animals in food utilization. Titus, Mehring \& Brumbaugh (1953) studied the food conversion of broilers at Io weeks of age. In an experiment with over 2000 chickens they found a mean food utilization of 3.05 . A strict comparison of the values for chickens and rabbits is limited by the differences between birds and mammals. The chicken is able to eat an experimental diet from the day of hatching, whereas the rabbit is not weaned from the mother until 6 weeks of age. However, the market age for broilers and rabbits is similar. Calculations made from the food consumption and growth after 6 weeks on the present experiment, and thus for animals 12 weeks of age, gave food efficiency values of $3 \cdot 5^{6}$ and $3 \cdot 15$, respectively, values similar to that listed above for broilers of approximately the same age.

It is difficult to compare the carcass weights in this experiment with those from other studies because carcass weight is defined in many ways. The definition of carcass weight for this study has been given already (p. 13). The mean values obtained in Exps. I and 2 were 59.9 and $59.3 \%$ of the live weight, respectively. On an anatomically comparable basis, Hammond's (1931) data for rabbits were very similar, the carcass weight averaging $56 \%$ of the live weight. Hankins, Hiner, Templeton \& 
Kellogg (195 I) at the United States Department of Agriculture Rabbit Station studied the physical composition of fryer (8-week-old) rabbits. They obtained carcass values ranging from 52 to $58 \%$ of the live weight.

In our study the edible portion of the meat was defined as muscle meat, liver, heart, kidneys, and the fat depots surrounding the kidneys, over the shoulder, and on the pelvic region. In Exps. I and 2, 56.2 and 52.2\%, respectively, of the live weight of the average animal was found in the edible portion. Hathaway, Champagne, Watts $\&$ Upp (I953) studied the meat yields of Dark Cornish, White Plymouth Rock and New Hampshire broilers at 12 weeks of age. In an experiment with 1800 chickens, 350 of which were dressed for meat yields, these workers found from 27 to $37 \%$ of the live weight to be edible meat. In this classification they included skin but not giblets or neck meat. Broadbent \& Bean (1952) reported $48.5 \%$ of the live weight of cross-bred broilers to be in the edible portion. Skin and giblets were included in the edible portion. McNally \& Spicknall (1949) found slightly below $50 \%$ of the live weight of Rhode Island Red broilers in the edible portion at $2 \mathrm{lb}$. live weight. Edible meat included neck meat and skin but not giblets.

Andrews \& Bohren (1947) reported a calorie efficiency of $12.6 \%$ for a group of twenty Plymouth Rock broilers killed at 12 weeks of age. They expressed the energy of the food and edible meat using Bryant-Atwater calorie values rather than in terms of the values obtained by bomb calorimetry. The edible portion included liver, heart and gizzard. The figure obtained is very similar to those obtained with rabbits in this study (12.34 and $10.52 \%$ ).

On the basis of this experiment the rabbit compares favourably with the chicken as an efficient producer of meat. The measures used in this study were protein and calorie efficiency, food efficiency and percentage edible portion.

\section{SUMMARY}

r. On a commercial stock diet food efficiencies of 4.04 and $3.47 \mathrm{~g}$ of air-dry food per g gain, respectively, were obtained for two groups of six rabbits over an 8-week experimental period.

2. The protein efficiencies of the two groups, measured as food protein stored as edible protein, were 17.93 and $13.94 \%$, respectively. Similarly, the calorie efficiencies of the two groups were $12 \cdot 34$ and $10 \cdot 52 \%$, respectively.

3. The edible portion was found to be $56 \cdot 2$ and $52 \cdot 2 \%$, respectively, of the live weight.

4. A comparison of these results with similar results for the chicken has been made, and it is concluded that the rabbit is as efficient a producer of meat as the chicken.

The authors are indebted to Dr C. M. McCay for his help with the housing and maintenance of the animals and to Dr G. Raymond Fisk for his assistance with the slaughter of the animals. 
Andrews, F. N. \& Bohren, B. B. (1947). Poult. Sci. 26, 447.

Broadbent, M. \& Bean, H. W. (1952). Poult. Sci. 3x, 447.

Hammond, J. (193 I). Yearb. nat. Rabbit Coun. p. 32.

Hankins, C. G., Hiner, R. L., Templeton, G. S. \& Kellogg, C. E. (195I). Physical Composition of Fryer Rabbits of Prime, Choice, and Commercial Grades. Washington: United States Department of Agriculture.

Hathaway, H. E., Champagne, G. B., Watts, A. B. \& Upp, C. W. (1953). Poult. Sci. 32, 968.

Huang, T. C., Ulrich, H. E. \& McCay, C. M. (1954). F. Nutr. 54, 62 I.

Hutchinson, J. C. D. (1947a). Brit. F. Nutr. 1, 2 19.

Hutchinson, J. C. D. (1947b). Brit. F. Nutr. 1, 23 I.

Hutchinson, J. C. D. \& Baker, C. J. L. (1949). Brit. F. Nutr. 3, 12.

McNally, E. H. \& Spicknall, N. H. (1949). Poult. Sci. 28, 562.

Titus, H. W., Mehring, A. L. Jr. \& Brumbaugh, J. H. (1953). Poult. Sci. 32, 1074.

\title{
An estimate of the weights of volatile fatty acids produced in the rumen of lactating cows on a diet of hay and concentrates
}

\author{
By D. A. BALCH* \\ National Institute for Research in Dairying, University of Reading \\ (Received 28 February 1957-Revised 13 August 1957)
}

With the increasing appreciation of the nutritional value to the ruminant of the volatile fatty acids produced by fermentation in the reticulo-rumen (hereafter termed rumen for brevity), the need has arisen to assess the amounts of such acids involved. When a cow consumes her diet in two equal meals at $12 \mathrm{~h}$ intervals, the mean weight of food digested in the rumen in any $12 \mathrm{~h}$ period can be calculated from the rumendigestibility coefficient. By incubating, under conditions similar to those present in the rumen, a sample of the diet with rumen liquor from the cow receiving that diet, a value for the weight of volatile fatty acids produced per unit of food digested can also be obtained. From these two values an estimate of the weight of volatile fatty acids produced in the rumen per day may be made. This paper presents the results of an attempt to estimate with this procedure the weights of volatile fatty acids produced in the rumen by two lactating cows during the feeding of two diets.

\section{EXPERIMENTAL}

\section{Animal management}

The experiment was made with two fistulated, lactating Dairy Shorthorn cows and was divided into two parts. In part I each cow received daily $16 \mathrm{lb}$. hay and cow A $20 \mathrm{lb}$. and cow $\mathrm{B} I 6 \mathrm{lb}$. concentrates: in part 2 each received $18 \mathrm{lb}$. ground hay and

* Present address: Department of Agricultural Chemistry, The University, Reading. 